\title{
A NEW CHILDREN'S ACT FOR SOUTH AFRICA: MAKING IT WORK FOR CHILDREN AND FAMILIES
}

\section{Roseline September}

\section{INTRODUCTION}

Numerous civil society organisations as well as the National Children's Rights Committee (NCRC) and UNICEF supported South Africa's post-apartheid government to institutionalise children's rights as a fundamental pillar of the new democracy. Towards this end, in 1995 the government ratified the UN Convention on the Rights of Child (1989) (the CRC). Drawing on this international standard, children's rights was enshrined in Section 28 of the SA Constitution (1996). Further to cover the particular vulnerabilities of African children, the government also ratified the African Charter on the Rights and Welfare of the Child (the ACRWC) in 2000. Collectively these instruments seek to ensure that children have a range of integrated political, civil, cultural and socio-economic rights. In addition to the general human rights to equality, a basic education and the right to dignity, children have additional socio-economic rights, including the right to family and parental care, or to appropriate alternative care when removed from their family setting; to basic nutrition, shelter, health care, social services and to be protected from maltreatment, neglect, abuse and degradation. By ratifying the international children's rights instruments and through its national constitutional provisions for children's rights, the SA government accepted an obligation to put in place mechanisms to realise these rights. However, the nation made these laudable commitments within a context of the huge resource and capacity challenges required for their implementation.

The apartheid regime of South Africa, with its racially discriminatory policies and structural inequalities left a legacy of a government bankrupt and in disarray, and a country with millions of children and their families in abject poverty. Almost thirteen years on, the inequalities remain stark. In 2005 there were over 18 million children in South Africa, constituting 39\% of the country's total population (Statistics South Africa, 2005). Of these, more than 13,5 million lived in households with an income of R2 500 or less per month (about US\$400). This means that significant numbers of children do not have their basic needs for health, food, housing, education and safety met, many living in households where the adults are unemployed. During 2004-2006 the unemployment rate for the economically active population remained almost consistently between $25 \%-26 \%$. Household data for 2005 indicate that $35 \%$ of South Africa's children live in informal housing or traditional dwellings, and $42 \%$ do not have access to water at their homes. African households continue to be disproportionately affected (Statistics South Africa, 2005).

In 1995 the government and the broad children's sector recognised that the old Child Care Act (1983) constructed under the apartheid government was entrenched in racial discrimination and inequalities, and was therefore no longer appropriate for South Africa. It was also evident that the old child welfare system was neither appropriate nor responsive to the expanded population that it had to serve. In fact, at that time it was described as falling apart as a result of its fragmentation and lack of essential resources (NCCAN, 1996; September, 2005). In response to these historic inequalities and the expanded need for services, as well as the fact that the types of interventions used before did not match the needs of the targeted populations, the new government has also instituted a number of policy shifts. In spite of the good intentions of the new government, these changes were mostly incremental and uncoordinated as well as lacking 
adequate resources to implement the better programmes envisaged. Consequently, the child and family welfare service system did not present a coherent, comprehensive and integrated system.

In order to respond to this state of affairs and to mainstream the core values of nondiscrimination, equity and social justice in a new institutional framework for the realization of children's rights, the government mandated the South African Law Commission to review existing legislation and to make recommendations for its reform to the Minister of Social Development. This process, which took more than ten years, culminated in the new comprehensive Children's Act, 38 of 2005 and the Children's Act Amendment Bill (the Act). The latter is presently being processed through the final legislative processes. These two pieces of legislation will be merged into a single Act that is expected to be completed and promulgated during 2008. The Act is generally regarded as an important instrument towards the realisation of children's constitutional rights. It is therefore broad in its coverage of children's rights to care and protection. Importantly, the Act provides for structures, services and other means to promote and monitor the development, protection and wellbeing of children. The sector expects the Act to serve as a primary driver for the transformation of the child and family welfare services system. It is intended that the Act will facilitate a more comprehensive set of services for vulnerable children and their families. This paper focuses on the development of the legislation, its objectives values and specific provisions of the Act intended to promote such comprehensive coverage.

\section{DEVELOPING THE NEW CHILDREN'S ACT}

In South Africa the Minster, through his Department of Social Development, is responsible for the protection and care of children and is therefore the primary custodian of the Children's Act. However, there are a number of key areas in the new legislation which require that the department work closely with other departments such as Health, Education, Justice, and Safety and Security. On this basis in 1997 this ministry instructed the South African Law Reform Commission (SALRC) to review the legislation affecting children in South Africa and to make recommendations regarding reform of the law. The Minister of Social Development also appointed a project committee, including representation from government departments and civil society organisations to work closely with SALRC. To secure the participation of the Parliamentary Portfolio Committee on Social Development, contact was maintained with this structure throughout the process.

The process that followed was extensive and for the most part widely participatory. To start the process the SALRC and the Project Committee drafted an issue paper which was published for comments in May 1998. The issue paper was then extensively consulted, using interactive workshops to facilitate input from a wide range of stakeholders. In order to ensure children's participation by hearing their voices and concerns, child-friendly materials were used in the workshops conducted with them and their responses were included in the main report. Furthermore, to enhance the research base of the inputs, the commission prepared a series of research papers on specific focus areas on, for example, child protection, children living on the street, children in out-of-home care and HIV/Aids. In addition, extensive research on legislation in other countries was conducted. These inputs from the various stakeholder consultations as well as the research papers constituted the basis for the discussion paper. The discussion paper released in 2001 was a bulky document of 1300 pages, produced in five volumes.

The consultation on this discussion paper started with a first workshop conducted with Parliamentarians, which was followed by another round of extensive consultations around the 
country. Numerous submissions were received. On the basis of these consultations, the Commission drafted its report and the drafting of the Bill commenced concurrently. Together with its extensive report containing preliminary recommendations on the law reform, the Commission submitted drafts of the Children's Bill to the Minister and the Chairperson of the Portfolio Committee. The drafters saw it as imperative that the recommendations for the new law should complement the realities of the provinces, as well as various government departmental policies and that it should articulate the values and provisions of the international treaties signed and ratified by the government (SALRC, 2003).

Up to this point the draft Bill included substantive provisions that envisioned comprehensive care and protection measures for children (Jamieson \& Proudlock, 2005). The vision of the Commission, supported by the project committee, was to develop a single comprehensive piece of legislation, including all statutory, common, customary and religious law affecting children. The recommendations especially included new provisions that emphasised the importance of social supports for families such as social security, prevention and early intervention, and it also proposed a greatly improved child protection system, including therapeutic support services.

In January 2003 the SALRC handed the final comprehensive draft Children's Bill to the Department of Social Development, which then entered into inter-governmental processes involving discussions and re-drafting with other relevant departments and ministries. After this process the draft Bill was sent to the State Law Advisors. During these "internal processes" the Children's Bill was dramatically reduced. This led to alarmed outcries from the children's sector, which felt strongly that much of the initial intent of the Bill was now lost. In particular, a strong lobby in the sector felt that the provisions dealing with extensive prevention and early intervention measures in support of children's own families had been inappropriately watered down. It was also felt that the measures, including those identifying adequate resources as necessary to establish an essential child protection system to respond more effectively to children's needs, were left out (Loffell, 2006). Opposing these concerns, the Department of Social Development argued that the provisions which had been removed could not be legislated for and should instead be provided for in either the regulations or other policy guidelines.

Early in 2003 the children's sector, constituting children's non-governmental organisations, formed a Children's Bill Working Group (CWG). The primary aim of the CWG was to coordinate, communicate and ensure a strong response from the sector as the Bill proceeded through the legislative processes (Proudlock, 2003). A particularly important feature of the CWG was its emphasis on mobilising service providers across the country and engaging with all relevant departments and the relevant Portfolio Committees in both houses of Parliament. The CWG also organised media campaigns to alert the general public to the progress of the Bill and maintain a website which provides continuous updates on the progress of the legislation. These activities facilitated ongoing participation and engagement with the formal law-making structures. The CWG also formed several sub-groups, each focusing on substantive areas of the Bill. These working groups developed discussion documents and conducted briefings and advocacy activities. A key focus of the work was to make formal submission to the relevant departments, to public hearings and to Parliament. As a result of the consistent lobbying and advocacy, many improvements in some of the sections of the Bill were made.

The Department of Social Development, on the basis of the submissions received on the Bill 75, redrafted the Bill. In 2004 the Bill was introduced by the Minister in the National Assembly. It was at this point that the Children's Bill was divided into two separate Bills, i.e. a section 75 Bill dealing with national and provincial competencies and a section 76 Bill including issues that fall 
within the provincial sphere of competency. Because Bill 75 affects both national and provincial governments, the legislative process that followed involved both houses of Parliament, i.e. the National Assembly (NA) and the National Council of Provinces (NCOP). This Bill passed through the National Assembly and was signed by the President in June, 2005 and became the new Children's Act Number 38 of 2005.

With regard to Bill 76 (the Amendment Bill), containing issues over which the provinces have jurisdiction, the Department of Social Development conducted workshops in the form of specialist consultations on each of the chapters in the Bill. The final Bill was drafted and tabled by the Minister at the NCOP. The NCOP conducted public hearings in all the nine provinces. On the basis of these public hearings and other submissions received, the NCOP gained the provincial mandates from the provincial legislatures. It is expected that the NCOP will vote on the Bill shortly and submit it to the NA for consideration and voting on it.

An important development during the process was the instruction from parliament that the proposed legislation must be costed to provide the provinces with an indication of what it will cost to implement the Bill. Consequently, a consultant (Mr Barberton from the Cornerstone Consultancy group) was appointed to conduct the costing of the Bill. This report has been released and immediately raised concern about the "affordability" of the Bill. The most significant outcome of the costing exercise was the fact that social welfare services in South Africa were historically under-funded and that most of its provinces are only capacitated to the extent of between $25-30 \%$ of what is needed to deliver on their mandates. In addition, the huge need for social workers to implement the Bill was highlighted. Currently there are 11372 social workers registered with the South African Council for Social Service Professions (SACSSP). The Cornerstone analysis only refers to the Department's mandate under this legislation - no other legislation or field of service is taken into account, while it is evident that the implementation of child rights depends on many other statutes and government departments. The figures from the Cornerstone study do not refer to the number of social workers needed by the country for all services - only those needed to implement the new Act. According to the projected needs in the country using a low capital investment scenario, the country will need 16504 social workers, and within a high scenario 66329 social workers by 2010 (Barberton, 2006).

Clearly, while it is essential to implement the Act as soon and as comprehensively as possible, there are growing concerns about the capacity of provincial governments and the local-level implementers to implement the Act.

The new Children's Act ushers in a new deal for children and potentially a turn-around strategy for their families. It is intended to break away from the emphasis on the needs of individual children with a move towards creating enabling environments and regulating support services. At the centre of this new approach is the introduction of prevention and early intervention services aimed at supporting children's own families before matters get so bad that they have to enter the more formalised child protection service system. Nevertheless, the Act also substantively improves the formal child protection service system and extends the court orders to provide for additional forms of care and protection options for children. As discussed in this paper, this new emphasis is established in the objectives of the Act as they are interwoven throughout the Act and intended to effect its implementation in practice. 


\section{THE OBJECTIVES AND PRINCIPLES OF THE NEW CHILDREN'S ACT}

In principle the Act is intended to fundamentally shift the way in which children are perceived and the way child welfare services are rendered. The primary objects of the Act are intended to give effect to children's constitutional rights to family and parental care, or as a last resort, to alternative care when removed from the family environment, to protection from maltreatment, neglect, abuse and degradation, and to the promotion of the best interests of the child (SA Constitution, 1996; SALRC, 2003). In addition, the new Act integrates the provisions of a number of international treaties and instruments such as The Hague Conventions on intercountry adoption and the UN Protocol on Trafficking. In order to mainstream the country's core values, pertaining to the care and protection of children, a set of distinct and clearly articulated objectives is included in the main body of the Act. These are:

- To preserve and strengthen families;

- To give effect to the constitutional rights of children;

- To give effect to the international laws binding on South Africa;

- To provide for structures, services and means which promote and monitor the well-being of children;

- To develop and strengthen community structures to care for and protect children;

- To protect children from discrimination, exploitation and all forms of harm or hazards;

- To provide care and protection to children in need of care;

- To recognise the special needs of children with disabilities;

- And generally, to promote the well-being of children (Children's Act, 2005).

While the objectives clearly indicated the intention of the Act, the drafters of the law felt that more was necessary to inform and standardise intervention practices. The Act therefore also includes specific underlying principles which are intended to guide the decisions of service providers when they deal with children. Whereas the objectives provide the intent and promote general enabling environments, these principles are aligned to children's constitutional rights and the promotion of their general wellbeing. It is also intended that the principles guide the implementation of all legislation applicable to children and all proceedings, actions and decisions by any organ of state in any matter concerning children. The following is a brief summary of the principles.

- Best interests of the child standard

Whenever, according to this Act, it is required that the best interests of the child standard be applied, a number of important factors must be considered.

- Best interests of the child paramount

In all matters concerning the care, protection and wellbeing of a child, the standard that the child's best interest is paramount, applies.

- Child participation

In all matters every child of such an age, maturity and stage of development has the right to participate and have his/her views considered.

- Recognition of children with disabilities and chronic illness

In any matter concerning a child with disability and chronic illness, due consideration must be given to the provision of appropriate care and the child's self-reliance and dignity. 
- Consideration of social, cultural and religious practices

Every child has the right not to be subjected to harmful social, cultural and religious practices.

- Access to information on health care

Every child has the right to have access to information on health promotion and the prevention and treatment of ill-health and disease, sexuality and reproduction.

- Access to court

Every child has the right to bring, and be assisted in bringing, a matter to a court which has jurisdiction over the matter.

- Enforcement of rights

A child, a child advocacy group or individual or a public-interest group, has the right to approach a competent court, alleging that a right in this Act or the Bill of Rights has been infringed.

- Responsibilities of children

Every child has responsibilities appropriate to his/her age and ability, to family, community and the state.

- Age of majority

A child, whether male or female, becomes a major upon reaching the age of 18 years.

Although these objectives and principles as provided for in Chapters One and Two of the Act are not binding in and of themselves, they set the overall intent and a general standard for the implementers, especially social services professionals and the courts. Such direction is especially important for social welfare policies in South Africa, where the actual implementation happens at many diverse, decentralised service delivery points. These underlying core values do not only create perceptions about the needs and rights of people, but also directs the choices that are made about what constitutes appropriate services for children and families (Gil, 1973; Gilbert \& Specht, 1977; September, 1992). Such clarity will hopefully ensure that the intent of the Act is not lost or subjected to differing perceptions and values of legislators, administrators, supervisors and individual service providers. Minow aptly captures how underlying values inform a particular discourse and consequently a particular set of actions.

The use of a rights discourse affirms community, but it affirms a particular kind of community: a community dedicated to invigorating words with power to restrain, so that even the powerless can appeal to those words. It is a community that acknowledges and admits the historical uses of power to exclude, deny, and silence - and commits itself to enabling suppressed points of view to be heard, to making covert conflict overt (Minow, 1990:229).

In the following discussion, I reflect on the core values as set out in the objectives and principles of the new Act and consider these in light of the realization of children's constitutional rights to be cared for within their own families and the states obligation to "Make provision for structures, services and means for promoting and monitoring the sound physical, psychological, intellectual, emotional and social development of children" (Children's Act, 2005, Section 2(d)).

\section{CHANGING PERSPECTIVES ON PARENTAL RIGHTS AND RESPONSIBILITIES}

The political, public and professional debates about the place and status of children in society have surprisingly not changed in their basic premises and features during the past 100 years (James \& James, 2004; Qvortrup, 1994; September, 1998). The debate remains centred on the 
boundaries between the private and public, state and family, and the individualisation of children in relation to their parents. While perceptions about the balance of power among these entities of care differ substantively, there is largely consensus on the importance of children's own families in their care and protection. Child welfare literature has also long favoured the position that children's own families must be strengthened, and only as a last resort should appropriate alternative care be considered. This position is affirmed in the Preamble of the UN CRC in its reference to the role of families and the obligation of the State:

...the family, as the fundamental group of society and the natural environment for the growth and well-being of all its members and particularly children, should be afforded the necessary protection and assistance so that it can fully assume its responsibilities within the community (also see Articles 3,16, 19,24,26 and 27).

South Africa's social welfare policies in general, and in particular this new Act, afford primary weight to preserving and strengthening families to care for and to protect their own children. The commendable difference of this new Act seems to be the explicit recognition that most parents who come to the attention of the chid welfare system may need additional support and assistance to care for their children. The Act consequently provides for a new range of provisions aimed at strengthening the capacities of families and communities.

As a starting point, Chapter Three of the new Act significantly changes the understanding of the relationships between parents, other care givers and children. It moves South African law away from the old notions of parental powers over children towards one based on the right of children to parental care, and the responsibility of parents to provide such care. It also defines more elaborately what exactly "parental care" entails in clause 11 of the Act. In principle this means that there can no longer be ambiguity about what constitutes the care role of parents or care givers. Previously the responsibilities of parents or other care-givers in relation to their children were not spelt out in detail, other than the duty to maintain children. This clause explains what the role of parents is, and ensures that this role is child-rights compliant, rather than being based on the notion of parental power that had previously characterised the parent-child relationship. Previously the emphasis was strongly on the parent's duties to maintain. This approach resulted in poor parents being "punished" by having their children taken away from them. In these instances the children became the primary victims.

In line with the UNCRC (Articles 2, 3, 9, 10 and 13), the new Act gives greater recognition to the rights of children to know and to be cared for by both biological parents, whether or not the parents are or were married. It is only when parents are unable or unwilling to take care of their children that the state is allowed to intervene. For example, where parents do not live together or have differences of opinion regarding the care of their children, the Act facilitates the child's best interest through the provision of joint parental responsibility agreements and parenting plans. These measures provide for amicable mediation and spells out the roles and responsibilities of each party regarding the care of the child (SA Constitution 1996; SALRC, 2003; Sloth-Nielsen, 2006).

To give further effect to the above intent, the old division of the constituent elements of parental power changes from Access, Custody and Guardianship to the new constituent elements of parental responsibility for Care, Contact and Guardianship of children. A biological mother of a child retains all three aspects of parental responsibility automatically. If she is herself an unmarried child and the biological father does not have parental responsibility, then her guardian is also the guardian of her child (Children's Act, 2005. Section 19). While unmarried biological 
fathers still do not necessarily have automatic parental responsibility, the new Act does go somewhat further in enabling unmarried men to be centrally involved in the care and protection of their children. With the new Act an extramarital father has parental responsibilities automatically if, at the time of the child's birth, he and the mother were living together in a permanent life partnership. He also has parental responsibilities where he and the mother are not living together, where he has consented to be identified as the child's father, or applied to be registered as the child's father, or paid damages under customary law and has contributed (or attempted in good faith to contribute) to the child's upbringing and maintenance for a reasonable period (The Children's Act, 38 of 2005, Section 21(1)).

The new law is also far more flexible in recognising that different people can perform different care functions in respect of the same child, and that parental responsibility can be shared between a number of possible care givers, including persons who are not the biological parents of the child, such as grandparents. Section 23 permits any person with any interest in the care, wellbeing and development of a child to apply to court (a high court in divorce matters, and children's court in other matters) for a care and/or contact order. For example, grandparents or other family members may apply when refused access to a child consequent upon the divorce of the child's parents. The specific arrangements will be captured in parenting agreements drawn up as part of the children's court proceedings. To regulate these arrangements and to provide for additional care options for vulnerable children, the new Act extends the types of orders that the court may make in relation to the care and protection of children.

The new Act, while promoting families as safe and protective havens for children, also recognises that families can be dangerous and harmful zones for children. In this regard and in keeping with the international law, the new Act (Section 61(1)(a-c)) strengthens children's participation. While children in the past were acknowledged as having a say in their own care arrangements, the new Act specifically provides that children have the right to participate actively, must be consulted and their opinions must be recorded in court decisions and matters that directly affect them. Moreover, children are now not only recognised as a party to a matter, but can also bring matters to the court. In this capacity they may now adduce evidence, question witnesses and produce argument. This provision strengthens children's position within families significantly and may serve as a general protection measure against neglect and abuse.

The new Act largely maintains the earlier provision and procedures for out-of-home placements of children, but improves the regulations and governance requirements of all foster care as well as child and youth care facilities to comply with children's rights and statutory obligations.

\section{STRENGTHENING CHILDREN'S OWN FAMILIES}

In placing the primary responsibility to care and protect children on families, the law defines these as heavy responsibilities. This is indicated in the new Act's definition of "care".

"Care" in relation to a child includes, where appropriate:

- within available means, provide the child with

- a suitable place to live

- living conditions that are conducive to the child's health, well-being and development; and

- the necessary financial support;

- safeguarding and promoting the well-being of the child; 
- protecting the child from maltreatment, abuse, neglect and degradation, discrimination, exploitation and any other physical, emotional or moral harm or hazards;

- respecting, protecting, promoting and securing the fulfilment of, and guarding against the infringement of, the child's rights set out in the Bill of Rights and the principles set out in Chapter 2 of this Act;

- guiding, advising and assisting the child in decisions to be taken by the child in a manner appropriate to the child's age maturity and state of development;

- guiding the behaviour of the child in a humane manner;

- maintaining a sound relationship with the child;

- accommodating any special needs that the child may have; and

- generally, ensuring that the best interests of the child is the paramount concern in all matters affecting such child.

Clearly, not all families are able to fulfil these functions adequately. Many families may need support and resources, and to rely on a range of social support systems (Andrews, 1980; Engelbert, 1994; Jenkins, 1981; Laird, 1979; September, 1991, September 2006). These systems, however, are not always responsive to families' needs. In some cases families are confronted with indifference or treated inappropriately or unfairly by child protection systems. Moreover, Thorpe (1974), Holman, (1975) and September (1998, 2005) have expressed concern about the fact that foster parents are sometimes treated more favourably than biological parents. Furthermore, the National Coalition for Social Services (NACOSS, 2003) notes that there are already numbers of children in out-of-home care who appear to be adrift as a result of the lack of adequate follow-up services resulting from the lack of social workers and resources.

It has also long been argued that scant attention is paid to the factors in society which serve to create poverty and stress for low-income families (Boushel \& Lebacq, 1992; Bond, 2002; Buckely, 2005). In particular, although child maltreatment occurs across economic status, a number of authors have indicated that children from poor families are over-represented in child abuse case loads (Channer \& Parton, 1990; Maluccio \& Fein, 1985; Pecorra, Carlson, Reese \& Bartholomew, 1992; Pelton, 1982; Roberts, 2000). In terms of their socio-economic status as well as their access to welfare goods and benefits, children are always dependent on their parents. In addition, legislation governing social welfare services relies strongly on families and family policies, which mostly assume that parents will care for their children. From this perspective children are viewed as dependent minors and not as distinct social beings (James \& James, 2004) and citizens.

These attitudes indicate fundamental barriers that perpetuate the exclusion of vulnerable children and families, which will have to be taken into account in developing services to meet the complex needs of children and their families. In particular, in order to meet the complex needs of families who access social welfare services, South Africa will have to systematically and purposefully construct the continuum of essential services that are necessary to support poor families. Poor families constitute large numbers of the country's population. Moreover, although government may have a number of poverty-alleviation schemes, more must be done to ensure the synergy and connectedness between them. For example, social welfare grants are currently a primary tool for poverty alleviation; the poor have access to free health care and education. However, the impact of these services could be improved if currently non-eligible families could access them and if these services could be more strategically aligned to specific development goals to enable families to exit from poverty. For this is to happen, access to other primary social 
services such as housing, sustainable employment and child care must be part of an organised, accessible and integrated poverty-eradication strategy. Presently there are very few examples of such integrated services programmes. If they exist they are small scale, for example, the Gauteng province's "Bana Pele" programme, which seeks to give children who are beneficiaries of social grants access to free education and school uniforms, subsidised transport and psychosocial support.

The objectives of the Act should enable moves to be made in this direction through its statutory provision of early childhood development (ECD), prevention and early intervention services to strengthen children's own families and to improve access to services in the communities in which they live.

\section{STATUTORY PROVISION FOR EARLY CHILDHOOD DEVELOPMENT (ECD), PREVENTION AND EARLY INTERVENTION SERVICES}

Clearly, the care and protection of children cannot be conceptualised or addressed in isolation from their families and communities. Presently, the quality of life of millions of South African children, who live in households of abject poverty, remains compromised by the poverty status of their families. A responsive child welfare system must facilitate open access for families to a range of integrated services. As suggested above, the Act promotes the principle of preserving and strengthening children's own families as the first line of intervention for children in need of care and protection. It recognises that families do better if they live in strong supporting communities which are capacitated to promote children's wellbeing and their protection against discrimination, exploitation and physical, emotional or moral harm or hazards. This objective of the Act strongly builds on an old African value system referred to as ubuntu, which embraces interdependency and mutual support within families and communities. This value serves as an important buffer in the light of the escalation of individual and family vulnerabilities as a result of HIV/Aids. Thousands of children and families are already very dependent on their neighbours and social support systems for assistance.

The new Act responds to the issues of poor families firstly by provisions for early childhood development (ECD), and secondly by provisions for prevention and early intervention. Technically, by the inclusion of the new provisions on early childhood development, prevention and early intervention services, the new Act makes provisions for families to access these informal helping networks and promotes the linkages of these with formal social services closer to where they are most needed. The strengthening of informal helping systems may potentially pave the way towards the establishment of a comprehensive and effective child protection system. The location of service points closer to informal helpers may assist with the earlier identification and helping of vulnerable children. The strengthening of local municipalities in this regard therefore remains crucial.

What happens during the earliest years of a child's life, from birth to 3, influences how the rest of childhood and adolescence unfolds (UNICEF, 2001:2). ECD is therefore globally promoted as an important poverty-reduction strategy. Children from poor and low-income families, compared to their better-off peers, are more likely to suffer from preventable diseases, fail in school, become involved in conflict with the law and become parents before they are ready to parent. They also often reach adulthood without the tools to access jobs and make a decent living (September, 2007a). In many countries, such as South Africa, this situation may be even further compounded by the impact of the HIV/Aids pandemic. As a result of parents dying, many orphans in poor communities are often taken in by extended families, who are mostly 
themselves also poor. In this regard, community-based ECD sites could play a key role in supporting caregivers and young orphans in poor communities by providing suitable care and stimulation for these children and their families (HSRC, 2007).

Realising the value of these programmes, government has launched a number of important strategies to strengthen the provision of early childhood development programmes. To strengthen its focus on ECD as an important sector, the government also announced its Expanded Public Works Programme (EPWP) to expand job opportunities for unemployed and low-income women in the ECD sector. In this regard, the government has increased its budget during the past two years significantly. However, the implementation is slow as the provinces require time to put their delivery mechanisms into place to act on this policy.

The new Act is expected to play a major role in the government's roll-out plan for the ECD sector. Specifically, it includes a duty on the relevant departments (social development, health and education) to develop an integrated ECD plan and regulate the registration, financing, service delivery and monitoring of ECD. Moreover, the Act promotes more equitable distribution and access of these facilities and programmes to poor children by assigning a role and functions for local municipalities.

The aim of provisions for prevention and early intervention, included in Chapter Eight of the Act, is to reach vulnerable children and their families before they have to receive statutory-level interventions.

The types and scope of the services will be described in a comprehensive national strategy on prevention and early intervention services. The new Act prescribes that the Minister of Social Development must develop such a strategy (Section 146). In practice this means that the government should detail the programmes and also fund them.

The Act describes prevention and early intervention programmes as services provided to families where there are children identified as being vulnerable to, or at risk of, harm or removal to alternative care. Prevention services are social development services provided to families with children with the aim to strengthen and build their capacity and self-reliance to address problems that may or are bound to occur in the family environment and which, if unchecked, may lead to statutory intervention (Children's Amendment Bill, 2007, Section 143(2b)). Both these definitions are broad and may be interpreted variously. However, by providing a detailed description of the purposes of early intervention programmes in Section 144, the Act strengthens the position of service providers and families by indicating a broad range of possible services to which families may have access. These services are aimed at:

- preserving a child's family structure;

- developing appropriate parenting skills and the capacity of parents and care-givers to safeguard the wellbeing and best interests of their children;

- establishing appropriate interpersonal relationships within the family;

- promoting the wellbeing of children and the realisation of their full potential;

- providing psychological, rehabilitation and therapeutic programmes for children;

- preventing the neglect, abuse or inadequate supervision of children and preventing other failures in the family environment to meet children's needs;

- preventing the recurrence of problems in the family environment that may harm children or adversely affect their development; 
- diverting children away from the child and youth care system and the criminal justice system; and

- avoiding the removal of a child from the family environment.

A key feature of the way the Act defines these services is the requirement that they be delivered in ways which are participatory and empowering for families. It is intended for the services to be based on national norms and standards. Furthermore, the Act specifically intends for the services delivered by different government departments and other service providers to be integrated to facilitate access to a full basket of services when needed. The norms and standards clause (Section 147) provides for the Minister of Social Development to consult regarding these services with the Department of Health and Education. These provisions undoubtedly suggest that the repertoire of services available to children and families should be comprehensive, integrated and supported.

The inclusion of prevention and early intervention provisions in the Act therefore has the potential to promote and realise children's socio-economic rights. The emphasis is no longer on blaming families who may have difficulties. Rather, it seems to be on creating enabling environments for children. Child protection decisions must be based on the principle of "what is in the best interest of the child". This position accepts the government's responsibility to secure an enabling environment for the wellbeing of all children.

\section{INCOME SUPPORT FOR VULNERABLE FAMILIES}

Child Support Grants (CSGs) payable to children under 14 years old has become a vital survival means for millions of children and their families. Presently, the government has seven types of social welfare grants, of which three target children. All the grants target individuals on a means-tested basis but none targets poor households specifically. With the increasing numbers of children orphaned as a result the HIV/Aids-related deaths of the parents, significant numbers of foster care parents are also benefiting from social welfare grants.

There are, however, complex issues and questions surrounding the provision of these grants in ways which promote the best interests of children. Firstly, the government's escalating budget on social welfare grants is a matter of concern for some social welfare policy analysts, who argue that the need of families is not so much for social welfare grants as for jobs, which the economy is not creating at the pace that is critically needed (May, 2000; Bond, 2002; September, 2007b). Secondly, access to the social welfare grants through the means test is often seen as dependent on the wits of applicants in "beating" the system. This means that millions more poor families who may be eligible for grants are not accessing them and remain excluded from the benefits these provide for their children. Thirdly, in response to a gap identified in the ages to which the grant applies, there is currently a major campaign to have the grant extended to include children beyond the present threshold of 14 years, at least until 18, or 21 if the children are still in school or studying. Related to these issues is the fact that the Act includes a progressive realisation clause. This means it only has obligations within its means. Section 4(2) of the Act states that, while recognising that competing social and economic needs exist, it requires that the different tiers of government "take reasonable measures to the maximum extent of their available resources to achieve the realization of the objects of this Act".

While the principles of the Act establish the ethical grounds for holistic services in support of children's own families, the ethical intent must be followed through with the political will and improvements on the institutional capacity level as well as the appropriation of adequate resources. 


\section{SUMMARY AND RECOMMENDATIONS}

While South Africa continues to make remarkable progress in many areas, we must also be brave and self-critical enough to recognise that our sustained growth and development is dependent on ongoing monitoring and evaluation of the policies and programmes that we design and implement. This new Act provides an opportunity to build in such checks and balances on various levels. Parliamentary institutions such as the portfolio committees must enhance their oversight role in terms of the performance expected from government departments as well as civil society through their constituency work. The Office on the Rights of the Child (ORC), located in the President's office with its provincial and local municipality-level counterparts, is also mandated to monitor the realisation of children's rights and wellbeing. The positive outcomes envisioned for children and families through this Act must be backed up by the development and implementation of a Strategic Implementation Plan for the Act (SIPA). These institutions, among others, could play a significant role in monitoring and evaluating the impact of the Act.

\section{A STRATEGIC IMPLEMENTATION PLAN FOR THE NEW ACT}

Leadership and coordination. The Minister of Social Development is the custodian of the Act and will therefore be the champion that will lead the implementation strategy. It will, however, be crucial to engage the other relevant ministers and government departments in the development of a SIPA to ensure a uniform approach and to agree on operational corporation, fiscal requirements and mechanisms for its appropriation.

An effective communication strategy. It will be imperative for the department of social development to design and role out a multimedia communication strategy. Central to this would be key messages to the general public on the intent of the Act.

Research-based demonstration projects. SIPA should include a call for evidence-based demonstration projects aimed at improving the quality of lives of families who are beneficiaries of government grants and social protection programmes. These would contribute to meeting the dire need for indigenous best practices (grounded theory) on successful interventions aimed at integrated and holistic provisioning of services to poor families, provided in ways that are empowering.

Investing in an effective child protection system. Every country that is serious about its children must be very serious about intervening in instances of child abuse and exploitation. The new Act sets the tone and prescribes statutory provisions for a potentially effective child protection system. The scope and formalisation of the child protection system as provided for in the new Act implies extensive resources, both human and infrastructural. If the government's intention is to continue to use non-governmental designated child protection agencies, then the funding formula and agreements with these important role players must be based on the premise that the government is the primary duty bearer. In this capacity the government must then take full responsibility for child protection services and must provide the full extent of the costs for such services if it chooses to involve non-government service providers.

Taking care of the carers (capacity building of the workforce). It is evident that the successful implementation of the new Act will be fully dependent on a competent workforce. The new Act introduces a new approach and substantively new services. The SIPA will have to include a comprehensive strategy for training and ongoing staff development. Presently, most child protection social workers are only equipped with the baseline undergraduate training programmes. This situation is extremely dangerous for employers, but particularly for every 
child and family who enters the child protection system. The government must therefore urgently make key decisions about the continued professional development of its staff. Many countries have invested in in-house training divisions, while others contract via conditional grants with external service providers. The Act provides a window of opportunity for government to consider its options and to ensure that this major gap is filled.

\section{CONCLUSION}

Melton and Limber (1992) observed that power is a dimension salient to both children and adults. A rights-based approach provides a way to ensure that power is used to build up constructively rather than to oppress. The new Children's Act presents a comprehensive expression of what South Africans wants for their children. It has the potential to socialise South Africans toward building a nation that demands the fulfilment of children's rights. But, hopefully, also a nation that understands and accepts that these rights impose on it the duty to protect the vulnerable and the powerless.

\section{REFERENCES}

AFRICAN CHARTER ON THE RIGHTS AND WELFARE OF CHILDREN. 1997. Available: http://web.amnesty.org/library/pdf/IOR630061998ENGLISH/\$File/IOR630 0698.pdf.

ANDREWS, C. 1980. Is blood thicker than local authorities? Social Work Today, 12(1):19-21.

BARBERTON, C. 2006. The cost of the Children's Bill: estimates of the cost to government of the services envisaged by the comprehensive Children's Bill for the period 2005 to 2010. Cornerstone Economic Research.

BOND, P. 2002. Fanon's warning: a civil society reader on the new partnership for Africa's development. Trenton, New Jersey: Africa World Press.

BOUSHEL, M. \& LEBACQ, M. 1992. Towards empowerment in child protection work. Children \& Society, 6(1):38-50.

BUCKELY, H. 2005. Reviewing children first: some considerations. Irish Journal of Family Law, November 3.

CHANNER, Y. \& PARTON, C. 1990. Racism, cultural relativism and child protection. In: Violence against children study group. Taking child abuse seriously. London: Routledge: 105-120.

CHILD CARE ACT 38. 2005. Government Gazette, 19, June 2006. Pretoria.

CHILD CARE ACT 74. 1983 (as amended by Act, 86 of 1991). Government Gazette, no. 8765. Cape Town: Cape and Transvaal Printers for Government Printers.

ENGELBERT, A. 1994. Worlds of childhood: differentiated but different. In: QVORTRUP, J.M., BARDY, G., SGRITTA \& H. WINDERSBERGER (eds) Childhood matters: social theory, practice and politics. Aldershot: Avebury: 285-298.

GIL, D. 1973. Unravelling social policy. Cambridge, MA: Sckenkman Publishing Co.

GILBERT, N. \& SPECHT, H. 1977. Planning for social welfare. New York: Prentice Hall.

HOLMAN, R. 1975. The place of fostering in social work. British Journal of Social Work, 5(1):3-29. 
HUMAN SCIENCES RESEARCH COUNCIL (HSRC). 2007. The Expanded Public Works Programme: opportunities and challenges. The early childhood education sector. Unpublished commissioned paper. Pretoria.

JAMES, A. \& JAMES, A.L. 2004. Constructing childhood. Basingstoke: Palgrave, MacMillan.

JAMIESON, L. \& PROUDLOCK, P. 2005. Children's Bill Progress Update: Report on amendments made by the Portfolio Committee on Social Development. Cape Town: Children's Institute, University of Cape Town.

JENKINS, S. 1981. The tie that binds. In: MALUCCIO, A. \& SINANOGLU, P. (eds) The challenge of partnerships: working with parents of children in foster care. New York: Child Welfare League of America.

LAIRD, J. 1979. An ecological approach to child welfare: Issues of family identity and continuity. In: GERMAIN, C. (ed) Social work practice: People and environment: an ecological perspective. New York: Columbia University Press.

LOFFELL, J. 2006. Children's Bill: what will change and the implications for practice. UWC training workshop. Unpublished document.

MALUCCIO, A. \& FEIN, E. 1985. Permanency planning revisited. In: COX, M. \& COX, R. (eds) Foster care: current issues, policies and practices. Norwood, New Jersey: Ablex.

MAY, J. 2000. Growth, development, poverty and inequality. In: MAY, J. (ed) Poverty and inequality in South Africa: meeting the challenge. Cape Town, London, New York: David Philip Publishers and Zed Books: 1-16.

MELTON, G. \& LIMBER, A. 1992. Human dignity and the experience of children: the UN Convention as a framework for policy in developed countries. In: HARVEY, J., DOLGOPOL, U. \& CASTELL, M. (eds) Proceedings of a National Seminar convened by the Children's Interests Bureau. Adelaide: Aquinas College.

MINOW, M. 1990. What children's rights mean to children: children's own views. In: FREEMAN, M. \& VEERMAN, P. (eds) The ideologies of children's rights. The Netherlands: Kluwer Academic Publishers: 183.

NATIONAL COALITION FOR SOCIAL SERVICES (NACOSS). 2003. Memorandum submitted to the Minister of Social Development, Dr Zola. Skweyiya, March. (Unpublished).

NCCAN. 1996. Draft national strategy on child abuse and neglect. Pretoria: Department of Social Welfare.

PARTON, N. 1985. The politics of child abuse. New York: St. Martin's Press.

PECORRA, P., CARLSON, I., REESE, S., \& BARTHOLOMEW, G. 1992. Developing and implementing risk assessment systems in child protective services. Protecting Children, (3):810,15 .

PELTON, M. 1982. Personalistic attributions and client perspectives in child welfare cases: Implications for service delivery. In: WILLS, T. (ed) Basic processes in helping relationships. London: Academic Press: 81-101.

PROUDLOCK, P. 2003. Progress report on The Children's Bill, 25 November 2003. Cape Town: Children's Institute, University of Cape Town. 
QVORTRUP, J. 1994. A new solidarity contract? In: QVORTRUP, J., BARDY, M., SQRITTA, G. \& WINTERSBERGER, H. (eds) Childhood matters: social theory, practice and politics. Vermont USA: Ashgate Publishing Company.

ROBERTS, M. 2000. Protecting children, supporting parents: government consultation on physical punishment. Child Right, 163:3-5.

SA CONSTITUTION. 1996 Act 108. The constitution of the Republic of South Africa. Pretoria.

SEPTEMBER, R.L. 1991. A qualitative evaluation of a family preservation program in UpState New York. Ithaca, New York: Cornell University. (MA. Thesis)

SEPTEMBER, R.L. 1992. International Conference on The Rights of the Child. Conference proceedings. Community Law Center, Cape Town: University of the Western Cape.

SEPTEMBER, R.L. 1998. The development of a protocol for the multi-disciplinary management of child abuse and neglect. Cape Town: University of the Western Cape. (Doctoral Dissertation)

SEPTEMBER, R.L. 2005. Protecting children where it matters most: In their communities and communities. Maatskaplike Werk/Social Work, 41(1):27-37.

SEPTEMBER, R.L. 2006. The progress of child protection in South Africa. International Journal of Social Welfare, 15(1):64-71.

SEPTEMBER, R.L. 2007a. The expanded public works programme: opportunities and challenges for the ECD Sector. The Social Work Practitioner/Researcher, 19(1):5-25.

SEPTEMBER, R.L. 2007b. Separating social welfare services and social welfare grants: Opportunities and challenges. Maatskaplike Werk/Social Work. In press.

SLOTH-NIELSEN, J. 2006. The Children's Act 38, 2005. Introduction chapters. Unpublished class notes for CYRTP. University of the Western Cape.

SOUTH AFRICAN LAW COMMISSION (SALRC). 2003. Report on the review of the Child Care Act (Part 3 of 3). Pretoria.

STATISTICS SOUTH AFRICA. 2005. Labour Force Survey, September 2004. Pretoria: Statistics SA.

THORPE, R. 1974. Mum and Mrs. So and So. Social Work Today, 4(22):691-695.

UN CONVENTION ON THE RIGHTS OF CHILDREN. 1989. Committee for the Rights of the Child. New York: United Nations.

UNICEF. 2001. The State of the World's Children. UNICEF, New York.

UNITED NATIONS CONVENTION ON THE RIGHTS OF THE CHILD ART. 12, Dec. 12 , (1989), UN General Assembly Document A/RES/44/25 Available: http://www.ohchr.org/english/law/crc.htm.

Professor Roseline September, Faculty of Community Health Sciences, University of the Western Cape, and Head of UNICEF, Cape Town. 